\title{
СУЧАСНІ ПІДХОДИ ДО ФІНАНСОВОГО ЗАБЕЗПЕЧЕННЯ ІННОВАЦЙНОГО РОЗВИТКУ АГРАРНОГО СЕКТОРУ
}

\author{
ДВНЗ “Прикарпатський національний університет імені \\ Василя Стефаника", \\ Міністерство освіти і науки України, \\ кафедра фінансів, \\ вул. Шевченка, 57, м. Івано-Франківськ, \\ 76018, Україна, \\ tel.: (0342) 59-61-76, 75-23-91, \\ e-mail: taras.vik@ukr.net
}

\begin{abstract}
Анотація. В умовах реформування аграрного сектору перед Україною постає проблема вибору стратегії інноваційного розвитку та джерел іiі фінансування. Метою дослідження $\epsilon$ теоретичне обгрунтування науково-методичних підходів і практичних рекомендацій щодо концепції фінансового забезпечення інноваційного розвитку аграрного сектору.

У процесі дослідження монографічний метод дозволив зазначити, що в країнах 3 сировинною економікою низький попит на інновації, тобто відсутність конкурентного промислового виробництва, не створює бази для формування інноваційного середовища та потенційних споживачів інновацій. Домінування видів діяльності зі спадною віддачею зумовлює реалізацію моделі за якої суспільні фінанси повинні направлятися на реалізацію в аграрному секторі завдань щодо його сталого розвитку в умовах зростаючого попиту на продукти харчування та необхідності збереження родючості грунту, розробку механізмів пріоритетного фінансування та реалізації цих завдань.

Розглянуто сучасні підходи до фінансування інноваційного розвитку. Зазначено, що в сировинних економіках інновації направлені на збільшення видобутку сировини та вирощування сільськогосподарських культур, на які $\epsilon$ попит на міжнародних ринках. Домінування видів діяльності зі спадною віддачею не дозволяє фінансувати інноваційний розвиток належним чином, як зі сторони держави, так і зі сторони потенційних споживачів інноваційних продуктів. Запропоновано для аграрного сектору України поєднання двох моделей, коли модель “держава інвестор” використовується в інноваціях, які мають в більшій мірі суспільний ефект (наприклад екологічні інновації) i, навпаки, модель “держава-регулятор” в інноваційній діяльності, що має яскраво виражений економічний ефект. Окреслено специфіку інноваційних процесів в аграрному секторі. Проаналізовано сучасні підходи до фінансового забезпечення інноваційного розвитку та фактори, які негативно впливають на розвиток агроінновацій в Україні.
\end{abstract}

Ключові слова: фінансування, інновації, моделі, інноваційний розвиток, аграрний сектор.

Sus T.Yo.

\section{MODERN APPROACHES TO FINANCIAL PROVISION OF INNOVATIVE DEVELOPMENT AGRARIAN SECTOR}

Vasyl Stefanyk Precarpathian National University, Ministry of Education and Science of Ukraine,

Department of Finance,

Shevchenko str., 82, Ivano-Frankivsk,

76018, Ukraine,

tel.: (0342) 59-61-76, 75-23-91,

e-mail: taras.vik@ukr.net 
Abstract. In the condition of reforming the agrarian sector, Ukraine faces the problem of choosing an innovative development strategy and sources of its financing. The purpose of the research is to provide theoretical substantiation of scientific and methodological approaches and practical recommendations as to the concept of financial support of innovative development of the agricultural sector. The monographic method made it possible to point out that the countries with resource economies have low demand for innovations, that is, the absence of competitive industrial production does not create the basis for the formation of innovative environment and potential consumers of innovations. The domination of types of activities with diminishing return leads to the implementation of a model whereby public finances should be directed towards the implementation in the agricultural sector of tasks for its sustainable development in the conndition of growing demand for food and the need to preserve soil fertility, develop mechanisms of preferred financing and implementation these priorities. Modern approaches to financing innovative development are considered. It was noted that in the resource economies, innovations are aimed at increasing the production of raw materials and growing crops that has demand in the international markets. The domination of the activities with diminishing return does not allow financing of innovative development in a proper way both for the government's part and the part of potential consumers of innovative products. It is proposed to combine for the agrarian sector of Ukraine two models where the model "government-investor" is used in innovations that has a greater social impact (such as eco-innovations) and vice versa the model "government-regulator" in innovation, which has a discernable economic effect. The specifics of innovative processes in the agricultural sector are outlined. The modern approaches to financial support of innovative development and factors that negatively influence the development of agroinnovation in Ukraine are analyzed.

Key words: financing, innovations, models, innovative development, agrarian sector.

Вступ. Розвиток глобалізаційних процесів та їх вплив на сучасну економічну систему України потребує від аграрного сектору суттєвої зміни якісних та кількісних параметрів діяльності. Одним з головних напрямів розвитку аграрного сектору на сучасному етапі повинна стати інноваційно орієнтована стратегія, яка здатна забезпечити високу конкурентоздатність продукції на міжнародних ринках за умов екологізації виробництва сільгосппродукції та її переробки.

У сучасних умовах реформування аграрного сектору перед Україною постає проблема вибору стратегії інноваційного розвитку та джерел ії фінансування. Важлива роль диверсифікації фінансового забезпечення розвитку інновацій на мікро - та макроекономічному рівнях підтверджується позитивним досвідом широкого впровадження інновацій та активізації інноваційних процесів в аграрному секторі розвинутих країн, направлених на забезпечення продовольчої безпеки цих країн за умови виробництва якісних продуктів харчування та збереження природного навколишнього середовища. Необхідність вибору оптимальних моделей фінансування інноваційного розвитку аграрного сектору, формування економічно i екологічно обгрунтованої інноваційної політики зумовлена амбітними планами України на роль провідного гравця на світовому ринку продовольства.

Аналіз останніх досліджень і публікацій. Дослідження різноманітних підходів до підвищення ефективності фінансового забезпечення інноваційного розвитку, виявлення та використання оптимальних комбінацій джерел фінансового забезпечення інноваційної діяльності присвячено багато робіт зарубіжних та вітчизняних науковців: М. Дем’яненка, П.Саблука, М. Маліка, П. Лайка, І. Лукінова, Ю. Лузана, М. Олсона, Д. Свіннена та інших.

Питання фінансового забезпечення інноваційного розвитку достатньо широко розкриті в наукових працях Г.О Андрощука [1], О. М. Колодізієва [2], О.П. Кириленко [3], О. Крисального [4] та інших. Актуальними залишаються питання розробки концептуальних положень фінансового забезпечення інноваційного розвитку аграрного сектору, які б відповідали сучасним фінансовим можливостям та особливостям його 
82 Сус Т.Й. Сучасні підходи до фінансового забезпечення...

забезпечення, виходячи 3 особливостей та специфіки сільськогосподарського виробництва.

Метою і завданням статті $\epsilon$ дослідження та теоретичне обгрунтування науковометодичних підходів i практичних рекомендацій щодо концепції фінансового забезпечення інноваційного розвитку аграрного сектору.

Виклад основного матеріалу. Використання суспільних фінансів для фінансування інноваційного розвитку залежить від економічної системи, що сформована в суспільстві та галузі економіки держави, пріоритетних напрямів економічного розвитку. В сучасних умовах розрізняють два основних підходи до формування фінансової політики та моделей фінансування інноваційного розвитку економіки. Перший підхід базується на стимулюванні пропозиції інновацій (SSI), а другий на стимулюванні попиту на них (DDI) [7].

Як зазначає М. Горський, ідеологія діяльності урядів розвинутих західних країн побудована на мінімізації державного втручання в економіку, обумовлює раціональне використання макроекономічних інструментів ( грошово-кредитна, бюджетна політика), формування ринкових умов (забезпечення вільної конкуренції, гнучка податкова система, стимулювання підприємницької активності ) та сприяє розробці і реалізації програм інноваційного розвитку. Тобто в рамках цієї парадигми попит на інновації виникає внаслідок ліквідації бар'єрів для нових постачальників інноваційної продукції на ринок для задоволення як уже наявного попиту так і скритого попиту (модель "Supply Side Innovation Policy” або "Стимулювання попиту інновацій”) [8].

В фінансовому забезпеченні інноваційного розвитку важливу роль відіграє держава. Досвід фінансування інноваційного розвитку зі сторони держави дозволяє виокремити дві моделі фінансування.

Як зазначає Кірдіна С.Г. “... модель “держава-інвестор” краще вписується в інституціональну систему, де суто ринкові відносини не відіграють переважної ролі, а “держава-регулятор" характерна для економіки, де суттєвий вплив мають ринкові відносини i приватна власність. Перевага першої моделі полягає в можливості централізовано спрямовувати ресурси у пріоритетні галузі інвестування й уникати циклічних коливань. Водночас ії̈ основною проблемою $є$ слабка мотивація потенційних інноваторів, а також високий ризик корупції та можливість розкрадання державних інвестицій на місцевих рівнях. Перевагами другої моделі $\epsilon$ висока інвестиційна активність ринкових суб'єктів і в зв'язку з цим більш висока швидкість технологічного оновлення виробництва. Її недоліками у сфері фінансування реального сектору $\epsilon$ ризики циклічності і надування “фінансових бульбашок” [9, с. 143-144].

В країнах 3 сировинною економікою низький попит на інновації, тобто відсутність конкурентного промислового виробництва не створює бази для формування інноваційного середовища та потенційних споживачів інновацій. В сировинних економіках інновації направлені на збільшення видобутку сировини та вирощування сільськогосподарських культур на які $\epsilon$ попит на міжнародних ринках. Крім цього, домінування видів діяльності зі спадною віддачею не дозволяє фінансувати інноваційний розвиток належним чином як зі сторони держави так і зі сторони потенційних споживачів інноваційних продуктів.

В Україні наразі переважає принцип стимулювання пропозиції інновацій та фінансова модель “держава-інвестор”, яка зумовлена концентрацією зусиль держави, а відповідно і витрат бюджетів різного рівня на реалізацію проектів інноваційного розвитку, збільшення фінансування з бюджету пріоритетних проектів. Такий підхід, крім зазначених вище, має суттєві недоліки та низьку ефективність внаслідок суттєвої затримки в часі бюджетного фінансування, зміни пріоритетів та урядів, хронічного дефіциту бюджету та скорочення видатків на інноваційну діяльність. Обмежені 
можливості бюджету обумовлюють відносно невисоку долю секторів економіки, охоплених потенційно ефективними інноваційними розробками, кількість яких скорочується. Низький рівень фінансування науки, рівень оплати праці науковців та морально застаріла матеріально-технічна база наукових установ, призвела до масового відтоку перспективних наукових кадрів за кордон. Державна фінансова політика в інноваційній сфері не носить системного характеру і не здійснюються кроки по переходу на модель стимулювання попиту на інновації. В першу чергу, на нашу думку, це пов'язано зі скороченням промислового виробництва та сировинним характером експорту. Практично, промислове виробництво перейшло на спрощені, енерго i матеріалоємні технології і за відсутності фінансових ресурсів та високої конкуренції на світових ринках не створює попиту на інноваційні продукти. Принцип інноваційного типу розвитку передбачає неперервний i цілеспрямований процес генерації ідей, розробки і впровадження в виробництво наукової продукції, фінансового забезпечення цього безперервного процесу, 3 метою підвищення ефективності суспільного виробництва та забезпечення сприятливих умов для саморозвитку інноваційних систем.

Для аграрного сектору України, який перебуває в процесі ринкових перетворень та $€$ інвестиційно привабливим як для вітчизняних так і для зарубіжних інвесторів найбільш раціональним є поєднання двох вищезазначених моделей, коли модель “держава інвестор” використовується в інноваціях які мають в більшій мірі суспільний ефект (наприклад екологічні інновації) i навпаки модель “держава-регулятор" в інноваційній діяльності, що має яскраво виражений економічний ефект.

Комбінація моделей та джерел фінансового забезпечення інноваційного розвитку аграрного сектору повинна враховувати його специфіку. Специфіка аграрного сектору полягає в тому, що він включає в себе:

1) галузі промисловості, які постачають сільському господарству засоби виробництва (тракторне і сільськогосподарське машинобудування, мінеральні добрива, засоби захисту рослин і т.д. );

2) сільське господарство (землеробство, тваринництво, рибництво та лісове господарство );

3) галузі зайняті переробкою та постачанням сільськогосподарської продукції споживачам (заготівля, переробка, зберігання, транспортування та реалізація продукції);

4) галузі інфраструктури, покликані забезпечувати сприятливі умови розвитку аграрного виробництва.

Інноваційний розвиток аграрного сектору значною мірою пов'язаний 3 біологічними факторами виробництва та впливу на агроценози, в першу чергу на родючість грунту та зміною кліматичних умов вирощування сільськогосподарських культур. В аграрному секторі інновації носять комплексний характер і в процесі виробничої діяльності взаємообумовлюють вплив промисловості на сільськогосподарське виробництво, переробну галузь та розвиток інфраструктури, сільських територій.

Вдосконалення агротехнологій зумовлює необхідність створення нових видів сільськогосподарської техніки (напр. впровадження грунтообробної технології No-till ), в свою чергу, створення механізованих комплексів по збиранню сільгоспкультур створює певні вимоги до селекції рослин з необхідними властивостями (помідори 3 твердою оболонкою для механізованого збирання), вимоги стосовно сільськогосподарської сировини для переробної галузі.

Інноваційні процеси в аграрному секторі характеризуються цілим рядом особливостей: 
84 Сус Т.Й. Сучасні підходи до фінансового забезпечення...

1) велика чисельність видів сільгосппродукції і продуктів ії̈ переробки, суттєві відмінності в технологіях вирощування та переробки;

2) залежність технологій від природно-кліматичних факторів;

3) специфіка використання біологічних активів;

4) висока залежність від інших галузей економіки в умовах диспаритету цін на продукцію;

5) порівняно низький рівень запровадження інновацій, їх еволюційний характер; процесів;

6) відсутність науково-обгрунтованого механізму фінансування інноваційних

7) не відпрацьованість механізму дифузії агроіновацій в середовищі середніх і дрібних сільгоспвиробників, зокрема в особистих селянських господарств;

8) диференційовані умови діяльності та високий рівень конкуренції серед сільгоспвиробників.

Специфіка аграрного виробництва визначає основну характеристику фінансового забезпечення інноваційного розвитку - довготривалість, прогнозованість i дотаційність. Інноваційна діяльність пов'язана з біологічними факторами виробництва та повільністю зміни і досягнення бажаних характеристик родючості землі, видів рослин і тварин. Відповідно сутнісною характеристикою інноваційної розвитку аграрного сектору $є$ його еволюційність та необхідність державної підтримки i регулювання, в першу чергу через механізм фінансового забезпечення. Дотаційність зумовлена специфікою сільськогосподарського виробництва - вид діяльності зі спадною віддачею, чистою конкуренцією на міжнародних ринках та значним впливом природно-кліматичних умов на результати діяльності.

Широкого застосування інституціально-еволюційний підхід набув в працях працях Р. Нельсона та С. Уінтера, серед українських економістів-аграрників елементи інститиуціонально - еволюційного підходу в аналізі перспектив та фінансування інноваційного розвитку аграрної сфери використовували Л. Курило, Ю. Лупенко, М. Малік, П. Саблук, С. Тивончук, О. Шпикуляк [ 10].

Доцільність такого підходу до фінансового забезпечення інноваційної діяльності випливає 3 тих тенденцій розвитку аграрного сектору в світі, які визначатимуть подальший розвиток людства. Сьогодні у світі зростає антропогенне і техногенне навантаження на довкілля, що призводить до руйнування агроландшафтів, зменшення біорізноманіття та зниження якості продукції в результаті забруднення залишками хімічних засобів захисту рослин та мінеральних добрив. Дані негативні тенденції зумовили необхідність вироблення нової стратегії фінансової підтримки інноваційної діяльності з боку держави, яка б нівелювала негативний вплив окремих інновацій, що впроваджуються в аграрному секторі. Це, а також зміна клімату в планетарному масштабі, зумовили встановлення та реалізацію парадигми сталого розвитку. Сталий розвиток аграрного сектору поставлений перед дилемою: $з$ однієї сторони-необхідність збереження природного навколишнього середовища та підвищення вимог до якості продуктів харчування, з іншої - зростання чисельності населення у світі та голодування понад мільярду населення, зумовлюють необхідність нарощування обсягів виробництва за рахунок усіх наявних ресурсів. Зміна клімату призводить до виникнення продовольчих криз, а інтенсифікація сільськогосподарського виробництва задля зростання продуктивності спричиняе деградацію сільськогосподарських угідь і в кінцевому результаті зменшення виробництва продовольства необхідної якості та кількості.

На державному рівні необхідно зважено підходити до нарощування обсягів сільгоспвиробництва та фінансово підтримувати інноваційні процеси, які забезпечуватимуть в першу чергу продовольчу безпеку держави та збереження 
(підвищення) родючості грунту, охорону навколишнього природного середовища. Важливо в програму реформ аграрного сектору імплементувати стратегію сталого агроекологічного розвитку та здійснювати фінансове забезпечення інновацій направлених на екологізацію сільгоспвиробництва, розглядаючи їх як найперспективніші інвестиції поряд з інвестиціями в людський капітал.

Виходячи із вищезазначеного, суспільні фінанси повинні направлятися на реалізацію в аграрному секторі завдань по його сталому розвитку в умовах зростаючого попиту на продукти харчування та необхідності збереження родючості грунту, розробку механізмів пріоритетного фінансування та реалізації цих завдань.

В Україні фінансування агроінновацій пов'язані 3 використанням наукових розробок, спрямованих на інтенсифікацію сільськогосподарського виробництва та нарощування обсягів експорту, забезпечення економічної ефективності виробництва продовольства. Тому інноваційні процеси в аграрному секторі носять еволюційний характер і стосуються перш за все виробництва елітного насіння, виведення нових сортів рослин, виведення нових порід тварин, використання перспективних технологій ïx утримання, створення більш продуктивної і енергоощадної сільськогосподарської техніки, нових засобів захисту рослин і препаратів для тварин тощо.

Такий тип інноваційного розвитку базується на принципах нарощування обсягів виробництва за рахунок якісного вдосконалення матеріально-речових елементів продуктивних сил, що в умовах кризи і недостатнього фінансування може здійснюватися великими сільгоспвиробниками через механізм впровадження зарубіжних технологій та зарубіжної техніки і обладнання, залучення іноземних інвестицій.

В умовах недостатньої уваги питанню збереження родючості землі та дотримання науковообгрунтованих норм сівозміни, фінансування інноваційних процесів не носить системного характеру та направлені на зростання продуктивності сільгоспвиробництва при недостатній увазі питанням охорони навколишнього природного середовища та якості продукції.

Стимулювання інноваційних процесів в аграрній сфері слід здійснювати в напрямках, які забезпечують перетворення сільського господарства на динамічну, збалансовану, адаптивну систему, здатну до постійного самовідтворення при ускладненні загальних умов екологічного і економічного розвитку, зміни клімату.

В Україні розвиток агроінновацій гальмується в силу наступних факторів:

- скорочення кількості та погіршення якості науково-дослідних розробок;

- недостатнє фінансування інноваційних розробок, які здійснюються науководослідними установами та вищими учбовими закладами;

- дефіцит кваліфікованих кадрів, відсутність фінансування для підвищення їх кваліфікації;

- низький рівень інформаційного забезпечення інноваційних процесів;

- недосконалість організаційного в тому числі правового і фінансового механізму для стимулювання інноваційних процесів;

- вкрай застаріла матеріально-технічна база наукових установ;

- низький попит на інноваційну продукцію серед потенційних іï споживачів в результаті економічної кризи.

Виходячи з вищезазначеного, вважаємо за доцільне використовувати суспільні фінанси для фінансового забезпечення інноваційного розвитку в такій пропорції: 75\% виділених коштів спрямовувати на інноваційну діяльність пов'язану з екологізацію сільськогосподарського виробництва, розвитку екологічного рослинництва i тваринництва, переробку та зберігання сільгосппродукції, а 25\% коштів 
86 Сус Т.Й. Сучасні підходи до фінансового забезпечення...

використовувати на агроінновації, які забезпечують зростання продуктивності та доходності сільгоспвиробництва.

Висновки. Для належного фінансового забезпечення інноваційної діяльності направленої на підвищення рентабельності та конкурентоспроможності агровиробників необхідно розробити механізм стимулювання та зацікавленості до самофінансування впровадження інновацій через методи непрямої державної підтримки, сприяння у залученні вітчизняних та зарубіжних інвестицій. Самофінансування $\epsilon$ основою інноваційного розвитку аграрного сектору, досвід індустріально розвинутих країн показує, що власні ресурси складають близько 70\% вартості всіх інвестицій. Власні фінансові ресурси агропідприємств є завжди обмеженими та можуть різко змінюватись під дією кон'юнктури на продукцію на зовнішніх та внутрішніх ринках, впливу природно кліматичних факторів. Крім цього розмір реінвестованої частини прибутку в інноваційну діяльність залежить від інвестиційної привабливості галузі, стимулів 3 боку держави для власників сільськогосподарських підприємств впроваджувати інновації.

1. Андрощук Г.О. Економічний механізм стимулювання інновацій. Проблеми науки. 2000. №1.С.2430.

2. Колодізєв О. М. Методологічні засади фінансового забезпечення управління інноваційним розвитком економіки: монографія Х. : ВД ІНЖЕК, 2009. 278 с.

3. Кириленко О. П. Фінанси : навч. посіб. Тернопіль : Економічна думка, 1998. 163 с

4. Крисальний О.В. Організаційно-економічні особливості інноваційної діяльності. Економіка АПК. 2005. №8. C.10-13.

5. Олсон М. Власть и процветание: Перерастая коммунистические и капиталистические диктатуры М.: Новое издательство, 2012. 212 с.

6. Swinnen Johan F. M. Agricultural credit problems and policies during the transition to a market economy in central and eastern Europe. URL: http: // www.agr.kuleuven.ac.be/aee/clo/prgwp/PRGWP06.PDF (Accessed 11 Sept. 2019).

7. Горский М. Как отремонтировать “инновационный лифт”. URL: http://www.forbes.ru/mneniyacolumn/idei/239647-kak-otremontirovat-innovatsionnyi-lift (дата звернення: 11.09.2019).

8. Горский М. Модели инновационного развития: SSI и URL:http://polit.ru/article/2013/12/17/ps_innov_1/ (дата звернення: 11.09.2019).

9. Кирдина С. Г. Институциональные модели финансирования реального сектора. Журнал Новой экономической ассоцииции. 2013.№ 2 (18). С. 129-157.

10. Саблук П.Т.та ін. Інноваційна діяльність в аграрній сфері: інституціональний аспект: монографія. К.: ННЦ IAE, 2010. 706 с.

\section{References}

1. Androshchuk, H.O. "Economic mechanism for stimulating innovation." Problems of science, vol. 1, 2000, pp. 24-30.

2. Kolodiziev, O. M. Methodological principles of financial support for management of innovative development of the economy:monograph, VD "INZhEK", 2009.

3. Kyrylenko, O. P. Finance, Ekonomichna dumka, 2009.

4. Krysalnyi, O.V. "Organizational and economic features of innovation activity." Ekonomika APK, vol. 8, 2005, pp.10-13.

5. Olson, M. Power and Prosperity Outgrowing Communist and Capitalist Dictatorships, Novoe izdatel'stvo, 2012.

6 Swinnen Johan, F. M. "Agricultural credit problems and policies during the transition to a market economy in central and eastern Europe." Agricultural Economics. Katholieke Universiteit Leuven, www.agr.kuleuven.ac.be/aee/clo/prgwp/PRG-WP06.PDF. Accessed 11 Sept. 2019.

7.Ghorskyi, M. "How to repair "innovative lift." Forbes, www.forbes.ru/mneniya-column/idei/239647-kakotremontirovat-innovatsionnyi-lift. Accessed 11 Oct. 2019.
8.Ghorskyi,
M. "Development
Models SSI
and
DDI."
POLIT.RU,

polit.ru/article/2013/12/17/ps_innov_1/ Accessed 11 Sept. 2019.

9. Kyrdyna, S. Gh. "Institutional models of financing the real sector." Zhurnal Novoj ekonomycheskoj assocyacyy, 2, 2013. pp.129-157. 
10. Sabluk, P.T. Innovative activities in the agrarian sector: the institutional aspect: monograph, NNC IAE, 2010.

УДК 336.77:338.3

doi: 10.15330/apred.1.15.87-94

Михайлів Г.В.

ФІНАНСОВА ПІДТРИМКА РОЗВИТКУ МАЛОГО ТА СЕРЕДНЬОГО БІЗНЕСУ В УКРАЇНI

\author{
ДВН3 “Прикарпатський національний \\ університет імені Василя Стефаника", \\ Міністерство освіти і науки України, \\ кафедра менеджменту і маркетингу, \\ вул. Шевченка, 57, м. Івано-Франківськ, \\ 76018, Україна, \\ тел.: (0342)55-32-32, \\ e-mail: kmim@pnu.edu.ua
}

Анотація. В сучасних умовах інтенсивного розвитку національної економіки важливого значення набуває функціонування малого підприємництва, яке суттєво впливає на розвиток вітчизняної економіки. У статті розкрито економічну сутність малого підприємництва, обгрунтовані форми і методи мікрокредитування малого підприємства, а також розглянуто зарубіжний досвід фінансового забезпечення мікрокредитування.

Основною метою даної статті є обгрунтування рекомендацій щодо побудови системи фінансового забезпечення розвитку малого і середнього бізнесу. Також здійснено аналіз фактичного стану становлення і функціонування малого та середнього бізнесу в Україні, форм і методів його фінансового забезпечення та визначено критерії і фактори, які впливають на розвиток малих підприємницьких структур.

Актуальність дослідження проблем, які піднімаються в даній статті, посилюється ще й тим, що повільність і суперечливість просування України шляхом ринкових реформ значною мірою зумовлені саме недооцінкою ролі та значенням малого та середнього бізнесу як структуро утворювального елемента ринкової економіки.

У процесі дослідження виявлено проблеми та визначено перспективи фінансової підтримки розвитку малого підприємництва на місцевому та регіональному рівнях. Обгрунтовано пропозиції щодо першочергових заходів ефективної фінансової підтримки та визначено головні перспективи фінансової підтримки розвитку малого і середнього бізнесу.

Ключові слова. фінансове забезпечення, кредитні відносини, мікрокредит, мікрокредитування, малий та середній бізнес, кредитні ризики, ефективність мікрокредитування, національна економіка.

Mykhailiv G.V. FINANCIAL SUPPORT OF SMALL AND MEDIUM BUSINESS IN UKRAINE

Vasyl Stefanyk Precarpathian National University, Ministry of Education and Science of Ukraine, Department of Management and Marketing, Shevchenko str., 82, Ivano-Frankivsk, 76018, Ukraine, tel.: (0342)55-32-32, e-mail:kmim@pnu.edu.ua 